\title{
Research on English Teaching Model Based on the Mobile Internet Environment
}

\author{
Guang-jin $\mathrm{LI}^{1}$ and Xiang-chong $\mathrm{GAO}^{1}$ \\ ${ }^{1}$ Nanjing City Vocational College, Nanjing Radio and TV University, Nanjing, China
}

Keywords: Mobile Internet environment, English teaching mode, Optimization of innovation.

\begin{abstract}
With the rapid development of information technology, the integration of network information technology and English curriculum fundamentally changed the nature of English teaching. At the same time, the English class teaching mode changed. It transformed from traditional classroom to modern English class under the network environment. Since then, with the innovation of mobile technology, the teaching location was no longer restricted. The change of the teaching mode had impacts on the teaching concept, teaching method and so on various aspects. $\mathrm{T}$ his paper briefly outlines the requirements of college English teaching and the technology of mobile communications, combing the practical application and advantages of English teaching model based on mobile Internet environment. It also points out the basic theory basis that required by the construction of English teaching mode under the mobile Internet environment and its realistic reserve conditions.
\end{abstract}

\section{Introduction}

All manuscripts must be in English, also the table and figure texts, otherwise we cannot publish your paper.

Please keep a second copy of your manuscript in your office. When receiving the paper, we assume that the corresponding authors grant us the copyright to use the paper for the book or journal in question. Should authors use tables or figures from other Publications, they must ask the corresponding publishers to grant them the right to publish this material in their paper.

Use italic for emphasizing a word or phrase. Do not use boldface typing or capital letters except for section headings (cf. remarks on section headings, below).

\section{Mobile Internet Technology}

Mobile technology composed of two parts of mobile communication technology and mobile terminal .Among them; the mobile communication technology includes wireless and cellular mobile communication systems. Wireless communication technology is embedded three types of network of WPAN (including blue tooth technology, infrared technology and radio frequency identification), WLAN (on behalf of the technology: Wi-Fi LAN technology) and WMAN (on behalf of the technology: WiMax) .Cellular mobile communication include GSM, CDMA, GPRS and 3G technology, etc. Mobile devices includes computers, personal digital assistants (pdas), digital audio players, smart phones, and so on user terminals.

Mobile terminals, mobile learning platform and resources, learning content and activity constitute a mobile learning system[2].In the process of learning, combined the three parts, different application mode was formed, mainly consists of this three kinds: Those three application modes [2] as shown in figure 1-1: 


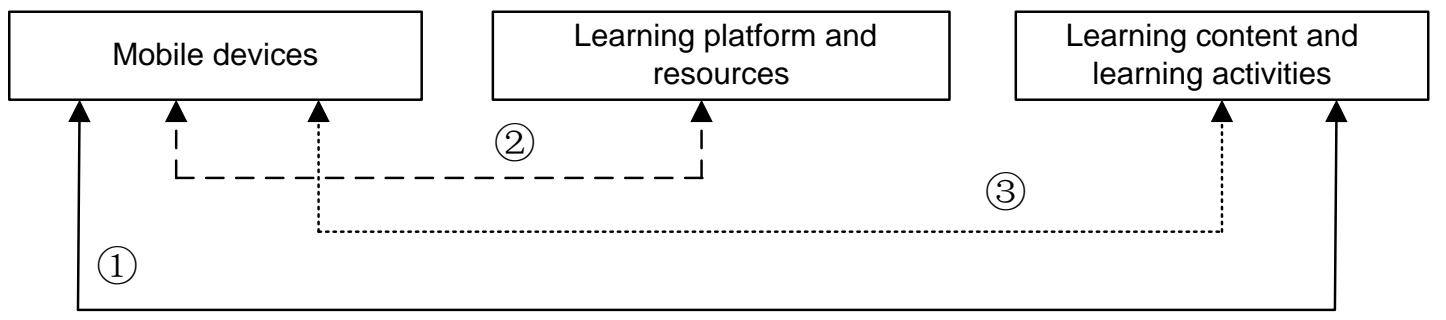

Fig. 1-1. The diagram of the application model of mobile learning system

The current hot spot is to reform the teaching modes combined with the characteristics of English subject and propose the English teaching model based on the mobile Internet environment relying on the mobile Internet technology. People are in hot pursuit of that [4].

\section{The Practice and Exploration of the English Teaching Model under the Mobile Internet Environment}

Network English teaching impacted the traditional education teaching idea, changed the teaching mode that takes teachers as the main body, and transformed to the teaching mode that considers independent, cooperative, inquiry learning as the core ideas. The diagram of the teaching mode based on the network mode [5] as shown in figure 2-1:

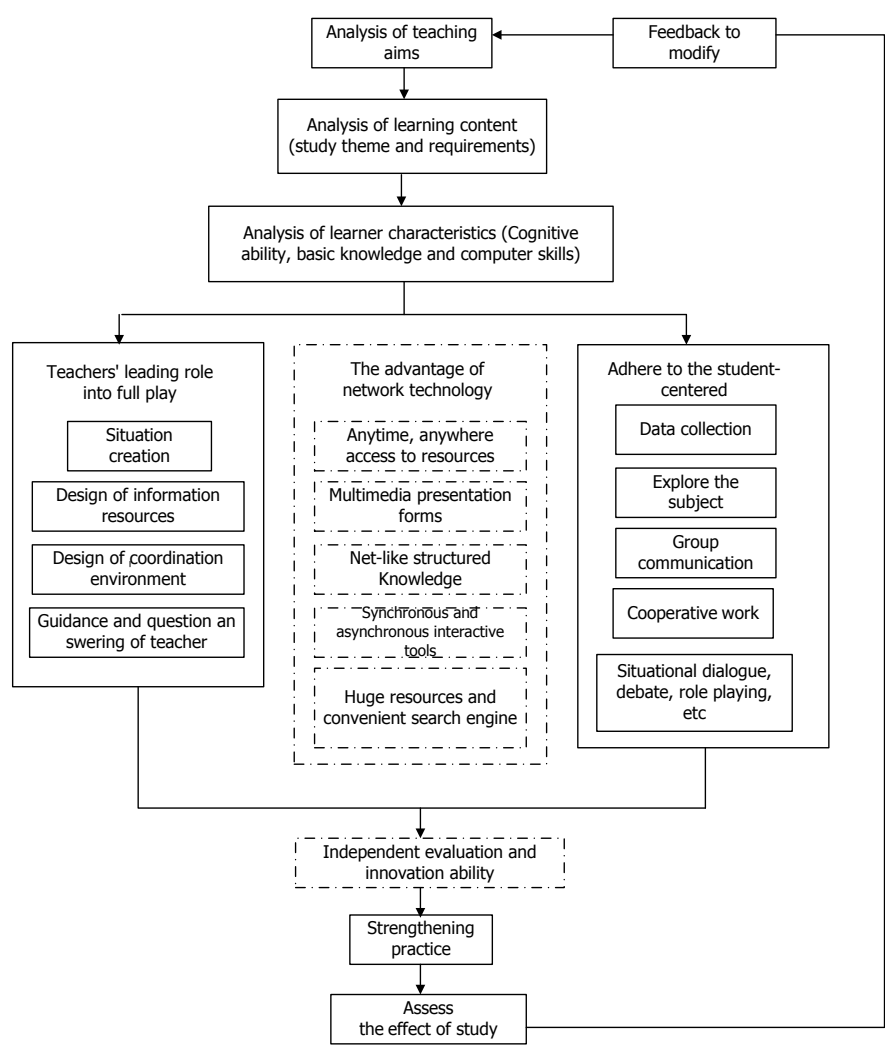

Fig. 2-1. The teaching mode under the network environment

For the practice application of English teaching under the mobile network, several kinds of practical instances are as followed [5]:

\section{Establishment of Foreign Language Websites to Assist English Teaching}

Due to the support of policy and the rapid development of education of colleges, the year-after-year enlargement of college enrollment makes the increase in student Numbers. 
Therefore, for now, the teaching methods used mainly by colleges are large classes, and the number of English classes per week is limited. Students demand for English knowledge and improvement of their language skills can not be satisfied only by that several times of English learning in class. Therefore; the establishment of English teaching websites can assist English teaching through online and offline.

On the foreign language website, students are free to visit columns related to English learning, and control and testing the specific or stage achievements of English study in their own way of thinking . This formed the two-way, multiway of English communication, realized interactive learning between learner and learner, between learner and teacher, which can stimulate more desire of the students to communication with foreign languages [4,5].

\section{Use Network Resources and Improve the Teaching of Oral English}

Spoken language is an important link in English teaching, however, our country now use a singleton traditional teaching mode with the color of "teacher-centered" and "based on reading comprehension and writing", neglected the cultivation of learners' oral English ability to a great extent, result in the lagging in oral English teaching and the present situation that learners' oral English ability is low. Apply is the source of interest.

Teachers combine material content with real life, guide students to use English to chat online, watch English film and television, listen to radio program, cultivate students interest and using abilities of English, exercise learners' oral English in a gradual way. V visiting English learning website under information technology environment, learners can improve their communicative competence on the basis of the understanding of foreign culture, history, customs, habits and customs. The process of language acquisition [5, 6] as shown in figure 2-2:

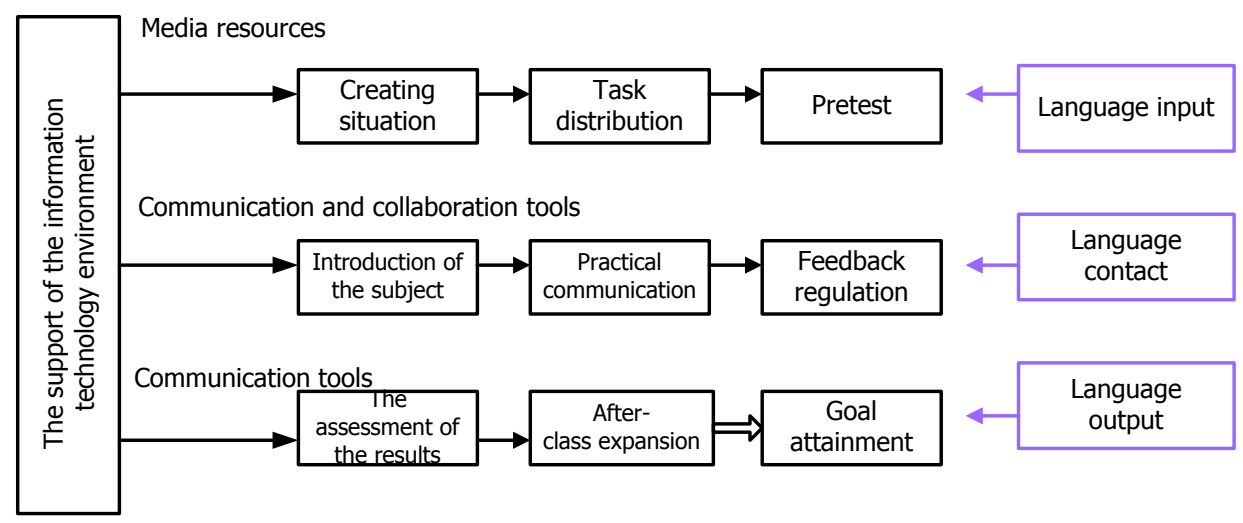

Fig. 2-2. Language acquisition process under the information technology environment

\section{Use Network Resources and Assist the Teaching of English Reading}

The teaching of English reading assisted with network will combine the characteristics of the English reading course with the student-centered autonomous learning environment; improve students' learning enthusiasm and initiative. According to the English reading teaching content and students' hobbies and interests, teachers arrange pointed network reading task reasonably, select high-quality reading content, and keep network real-time monitoring, create a comprehensive reading way to inspire students' enthusiasm for learning, and their self-confidence. At the same time, the platform of network that assist the teaching of reading may also provide a wide space for the interaction between teachers and students [5,7]. 
The Advantages of English Teaching Mode under Mobile Internet Environment

\section{Not Restricted by Time and Space}

The extremely prominent performance of teaching English under mobile Internet environment is to break the limitation of time and space, no longer constrained by the tens of minutes in class. Through the mobile terminal, learners are free to arrange the time and place to obtain the learning resources from mobile learning platform, repeatedly watch the difficult parts, to overcome the existing deficiencies in traditional English teaching mode.

\section{Rich Resources, Large Amount of Information}

The Internet has a lot of English teaching resources and provides us rich, novel, comprehensive, vivid and practical English material. It has wide coverage, with humanities and geography knowledge in it. At the same time, easy to search and find is one of the features of the Internet. English teaching website provides various training, including listening comprehension, grammar, writing, etc. In the process of learning, we can not only see English description, but also see the combination of images and sounds. Such presentation not only can make students have more profound and thorough understanding of the learning content, but also greatly arouse the students' interest and passion of learning English.

\section{Normalize the Students' English Pronunciation}

Because English is not our first language, the pronunciation of English teachers, and their master of English knowledge is yet to be improved to some extent. Students' pronunciation impacted hugely by teachers' in the traditional teaching mode. The common and widespread phenomenon is that current students' pronunciation is inaccurate. English teaching model based on mobile Internet environment can effectively circumvent this problem. If the teaching content read and recorded by English-speaking people, the accuracy of the pronunciation is very high. That will be beneficial to the students' oral English ability.

\section{Provide Authentic Language Environment}

Create a real language environment conducive to English learning. English learning under the multimedia network can provide such a real language environment.

\section{Promote Communication between Learners; Improve Teachers and Students' Ability of Communication and Autonomic Learning}

On English learning site, the teacher use rich English learning resources create good English communication environment, and guide students to have a lot of simulation communication, mobilize students' learning initiative. Students can improve their English communicative competence by thinking directly in English. In addition, English learning under the network environment from the true sense realize individualized teaching. Students' creativity is no longer limited by the same lectures, same teaching materials and same activities.

\section{Building Theoretical Basis and Realistic Reserve Conditions of English Teaching Mode under the Mobile Internet Environment}

The real conditions to build English teaching mode under the mobile Internet environment is the organic combination of network multimedia teaching mode and the characteristics of English subject [3].Construct doctrine study theory that based on cognitive learning theory is the 
theoretical basis of the English teaching reform. Learners help each other through collaboration, discussion, communication, building actively with the necessary information resources. The rapid development of information technology provides learners a no longer boring platform. On the basis of its theory, the developing trend of teaching reform in our country is to improve the teacher-centered, single teaching mode to the personalized, self-serviced teaching model. It has achieved some results.

\section{Conclusion}

English teaching mode under the mobile Internet environment that guided by modern education concept brought a great change to the traditional English teaching model. It also had great ideological innovation [3]. Under this kind of mode, the interaction between teachers and students became more frequently and deeply, the access to knowledge became more convenient and time, space became no longer restricted. When real scene provided by the rich learning platform, internal learning resources regulate the learners' pronunciation accuracy to a certain extent. At the same time, the learner's independent initiative became stronger. This paper briefly outlines the requirements of college English teaching and the technology of mobile communications, combing the practical application and advantages of English teaching model based on mobile Internet environment. It also points out the basic theory basis that required by the construction of English teaching mode under the mobile Internet environment and its realistic reserve conditions. Therefore, English teaching mode under mobile environment should continue developing and perfecting, popularizing, so as to make greater contribution to English teaching.

\section{References}

[1] X. B. Sui. Research on Optimization of College English Classroom Teaching under the Network Environment - Based on Empirical Survey in Jiamusi University. Shanghai Foreign Language University. 2013

[2] J. Zhang. Research on College English Hybrid Teaching Model Supported by Mobile Technology. Jilin, Northeast Normal University. 2011.

[3] X. Sun, F. M. Meng. Reform and Innovation of English Teaching Pattern under the Network Environment. Education and Vocation. (36): 112-113, 2013.

[4] M. P. Chen. Research on English Teaching Model under the Internet Environment. Education of Science and Technology Innovation. (5): 198-199, 2009.

[5] F. Yuan. Research on English Teaching Mode under the Network Environment. Journal of Jiamusi Education Institute. (5): 327-330, 2010.

[6] Z. Liang. Research on Junior Middle School English Oral Task-based Teaching Model under the Information Technology Environment. Jilin, Northeast Normal University, 2013.

[7] Y. Y. Wang. Discussion of College English Reading Learning Strategies under the Network Environment. Cultural Geology, (8): 200-201, 2014. 